Vol.45, n. 4 : pp. 525-530, December 2002

ISSN 1516-8913 Printed in Brazil

BRAZILIAN ARCHIVES OF BIOLOGY AND TECHNOLOGY

AN INTERNATIONAL JOURNAL

\title{
Performance Analysis of a Trickle Irrigation Subunit Installed in an Apple Orchard
}

\author{
Olívio José Soccol $^{1 *}$, Mario Nestor Ullmann ${ }^{1}$ and José Antônio Frizzone ${ }^{2}$ \\ ${ }^{1}$ Depto de Engenharia Rural; CAV; Universidade do Estado de Santa Catarina; C. P. 281; 88520-000; Lages - SC - \\ Brazil. ${ }^{2}$ Depto de Engenharia Rural; ESALQ; Universidade de São Paulo; C. P. 9; 13418-900; Piracicaba - SP - Brazil
}

\begin{abstract}
Studies were carried out to evaluate the "xique-xique" irrigation system of a trickle irrigated subunit. Initial results showed that the system's performance was average, any Emission Uniformity, Statistical Uniformity and Coefficient of Global Variation were 74.51, 77.69, and 22.31\%, respectively. The efficiency parameters were below expectations, and values of Application Efficiency (Ae), Storage Efficiency (Se), Deep Percolation (Dp), Deficit Degree (DD) and Adequacy Degree (a) were 100, 47.83, 0, 52.17 and 0\% respectively. By adopting new management procedures, it was possible to improve the system's efficiency, reaching values of 90.20, 91.68, 9.80, 8.32 and $52.87 \%$ for $A e, S e, D p, D D$ and " $a$ ", respectively.
\end{abstract}

Key words: Irrigation, efficiency, uniformity

\section{INTRODUCTION}

The evaluation of operating irrigation systems aims the understanding of the system's adequacy and the determination of the necessary procedures for improving the system's performance. It is recommended that the evaluation should be carried out soon after the system's establishment in the field, and periodically repeated, especially when considering trickle irrigation systems, due to their sensitivity to operational conditions along the time (Keller and Blisner, 1990). Martín-Benito (1993) stated that in an overall evaluation, many aspects showed be taken into account, resulting, in a new project and system calculations, based on real rather than empirical data. According to Frizzone (1997), despite the vastness of the evaluation issue, tests are the part of the procedures that deal specifically with the measurement of values characterizing the behavior of a specific specimen to provide a certain kind of data. Tests to determine functional attributes, related to resistance and durability, are generally defined through technical specification rules and/or test methods. Therefore, it is clear that in many cases, the performance evaluation is understood as the group of tests with emitters belonging to a certain piece of equipment composing the irrigation system. The following are the essential objectives in a performance evaluation: i) determining the system's efficiency, as it has been operated; ii) determining when the system can be effectively operated and whether it can be improved; iii) obtaining helpful information that may be used to project other systems; iv) obtaining information that enables the comparison of several irrigation systems and operational procedures, as the basis for management. Quality has become a key issue

* Author for correspondence 
in the last decades. It represents the gains resulted from different ways of producing goods and services, which can be easily applied to irrigation. In irrigation, quality is expressed by some performance parameters, labeled as the following three key words: uniformity, efficiency and adequacy degree.

Uniformity relates to the performance parameters associated with the variability in the amount of irrigation, constituting a value that characterizes the whole irrigation system. Generally, the irrigation uniformity is expressed by uniformity coefficients, which are measurements of statistical dispersion, without a physical meaning but related to the irrigation quality. Efficiency is used to identify parameters that, through a proportion among water amounts involved in the irrigation process, express a relationship among the following water volumes: collected at the source; provided to the subunit via irrigation system; necessary to the plant; stored in the soil within suitable depth to the roots; lost by evaporation and wind, percolation and runoff. Quality is influenced by uniformity. The adequacy degree was proposed to express how well the irrigation system satisfies the needs of the crop in relation to the water added to the system in order to keep the product quality and vegetal productiveness at an economical level. The emitter's flow of a trickle irrigation system is mainly affected by hydraulic dimensions, manufacturing variations, temperature and clogging of emitters (Bralts et al., 1981 and Bralts \& Edwards, 1986). If the emitter's flow is turbulent, it is less affected by temperature and, if the water taken into the system can be controlled by filters, which are essential for trickle irrigation systems, the emitter's variation will be only affected by pressure and manufacturing variations (Anyoji and $\mathrm{Wu}, 1994$ ).

The aims of this work were to evaluate the performance of a trickle irrigation system, xiquexique type in an apple orchard by means of the parameters analysis (uniformity, efficiency and adequacy degree) and to suggest management alterations to improve its performance.

\section{MATERIALS AND METHODS}

Tests were carried out in the experimental area of the Hydraulics and Irrigation Department of the Agronomy College - University of Santa Catarina State - UDESC, in Lages municipality - SC. The irrigation system evaluated was in a subunit with trickle irrigation system, xique-xique type, comprising 6 lateral lines, 53m long, 3m apart from each other, set in a flat area. The lateral irrigation lines were of polyethylene $(16 \mathrm{~mm}$ diameter) and the derivation line of polyvinylchloride (PVC) $(50 \mathrm{~mm}$ diameter), with a screen filter at the beginning. The water supply was taken from a reservoir with constant level, located $5 \mathrm{~m}$ high. The system was dimensioned in order to promote $10 \%$ of flow variation throughout the lateral and derivation lines.

The orifices (emitters) were made with a veterinarian needle, enabling an internal diameter of $1 \mathrm{~mm}$, spaced $2 \mathrm{~m}$ apart from each other and were finally covered with a polyethylene pipe segment (glove) (19mm diameter and $10 \mathrm{~cm}$ long). The orifices were previously set in laboratory conditions for pressures varying between 5.0 and 105.0 , with $5.0 \mathrm{kPa}$ intervals. The respective volumes were transformed to flow-rate considering 20 pipe segments with 12 orifices each one. From the flow and pressure data, a typical flow-pressure equation for the emitter was generated through linear regression and the discharge coefficient was determined. Both field and laboratory tests were carried out at around $22^{\circ} \mathrm{C}$ water temperature.

Flow measurements were taken at the beginning, $1 / 3$ and $2 / 3$, and at the end of the lateral line, located at the beginning, $1 / 3$ and $2 / 3$, and at the end of the derivation line of the irrigated subunit, totaling 16 points of measurement (Merrian and Keller, 1978), which was same as the number of plants (as the system had an emitter per plant). Flow rates were determined by direct process, collecting the volume in a proper container and measuring it in a graduated cylinder $(1,000 \mathrm{~mL})$. The collection time was set to 5 minutes, enough to obtain a minimal volume of $200 \mathrm{~mL}$, according to ASAE EP 458 (1996). Tests were conducted for pressures of $42.6 \mathrm{kPa}$, measured at $40 \%$ of the lateral line length, repeating the procedure three times.

The irrigation uniformity of the area was determined by means of three indexes:

a) Emission Uniformity suggested by Keller and Karmeli (1974) expressed as:

$$
E U=\frac{\bar{q}_{25}}{\bar{q}} 100
$$


where,

$E U$ - emission uniformity (\%);

$\bar{q}_{25}$ - average of the $25 \%$ lowest values of flow rate $(\mathrm{L} / \mathrm{h})$;

$\bar{q}$ - average flow rates $(\mathrm{L} / \mathrm{h})$.

b) Statistical Uniformity term was suggested by Wilcox and Swailes (1947) for the evaluation of sprinkling irrigation systems, with the emitters' precipitation as the random variable. Bralts et al. (1987) developed a similar statistical approximation for trickle irrigation systems, presenting the emitters' flow rate $\left(\mathrm{q}_{\mathrm{i}}\right)$ or the volume $\left(\mathrm{V}_{\mathrm{i}}\right)$ as the random variable, resulting in the following equation:

$$
S U=\left(1-\frac{S_{q}}{\bar{q}}\right) 100
$$

where,

$S U$ - statistical uniformity (\%);

$S_{q}$ - standard deviation of the emitters' flow rate $(\mathrm{L} / \mathrm{h})$.

c) Coefficient of Global Variation determined by means of the flow rates measured during field tests, including hydraulic and manufacturing effects, and also those due to the clogging of the emitter. It is given by the equation below:

$$
C G V=\frac{S_{q}}{\bar{q}} 100
$$

where,

$C G V$ - coefficient of global variation of the flow rate $(\%)$.

In order to verify how adequate the uniformity of the system was, the procedures recommended by Bralts et al, (1987), Pizzaro (1996) and ASAE EP 458 (1996) were employed.

The irrigation efficiency has been evaluated through different approaches. In this work, the Application Efficiency $(A e)$, Storage Efficiency $(S e)$, Deep Percolation $(D p)$, Deficit Degree $(D D)$ and Adequacy degree $(a)$ were used, assuming normal distribution of the data, according to the methodology described by Anyoji and Wu (1994), as follows:
- Application Efficiency:

$$
A e=\left[\frac{V S}{V d}\right] 100
$$

where,

$A e$ - application efficiency (\%);

$V_{S}$ - volume of water stored in the root zone after irrigation (L);

$V d$ - volume of water derived to the subunit (L).

- Storage Efficiency:

$$
S e=\left[\frac{V S}{V r}\right] 100
$$

where,

Se - storage efficiency (\%);

$V r$ - water volume necessary to supply the deficit in the root zone (L).

- Deep Percolation:

$$
D p=\left[\frac{V p}{V d}\right] 100
$$

where,

$D p$ - deep percolation (\%);

$V p$ - volume of water percolated below the root zone $(\mathrm{L})$.

- Deficit Degree:

$$
D D=\left[\frac{V d}{V r}\right] 100
$$

where,

$D D$ - deficit degree (\%);

$V d$ - deficit volume (L).

- Adequacy Degree:

The calculation procedure to determine the portion of area receiving at least the required volume " $a$ " consists in determining the area under the Normal Distribution curve, using numerical methods, polynomials or the Normal Distribution Table. It was employed the polynomial suggested by Zelen and Severo (1972) in the present work.

From the evaluation data, the simulation of the increasing irrigation volumes applied was carried out by means of the increase in the irrigation time. For each time value, the efficiency parameters were calculated in order to determine the point that promoted the best conditions for the system's performance. 


\section{RESULTS AND DISCUSSION}

The peculiar emitter's equation, Equation (8), whose determination coefficient was 0.981 , was adjusted by means of the pressure and flow rate data.

$$
q=4.0798 h^{0,421}
$$

where,

$q$ - emitter's flow rate $(\mathrm{L} / \mathrm{h})$;

$h$ - emitter's pressure $(\mathrm{kPa})$.

The average Discharge Coefficient was $81.22 \%$. The Coefficient of Manufacturing Variation $\left(\mathrm{CV}_{\mathrm{q}}\right)$ was obtained from the average standard deviation of the flow rates measured in the laboratory test considering a pressure of $50.0 \mathrm{kPa}$, with initial value of $19.80 \%$. According to the classification proposed by Solomon (1979), and ASAE EP405 (1984), initial value of uniformity was considered unacceptable. The low manufacturing uniformity was due to the little control of the manual process for making the orifices. Table 1 presents mean values of three repetitions for collected volumes, flow rate and diary irrigation per emitter, considering the project's irrigation time at each emission point in the test.

$\underline{\text { Table } 1 \text { - Mean values of collected volume, flow rate and irrigation volume/plant.day. }}$

\begin{tabular}{ccccc}
\hline Lateral & Emitter & $\begin{array}{c}\text { Collected volume } \\
\boldsymbol{V}_{\boldsymbol{i}}\left(\mathbf{c m}^{\mathbf{3}}\right)\end{array}$ & $\begin{array}{c}\text { Flow rate } \\
\boldsymbol{q}_{\boldsymbol{i}}(\mathbf{L} / \mathbf{h})\end{array}$ & $\begin{array}{c}\text { Irrigation volume } \\
\boldsymbol{V}_{\boldsymbol{o}}(\mathbf{L} / \mathbf{p l a n t . d a y})\end{array}$ \\
\hline \multirow{4}{*}{ beginning } & beginning & 707.50 & 8.49 & 3.396 \\
& $1 / 3$ down & 653.00 & 7.84 & 3.136 \\
& $2 / 3$ down & 887.50 & 10.65 & 4.260 \\
& end & 898.00 & 10.78 & 4.312 \\
& beginning & 661.00 & 7.93 & 3.172 \\
& $1 / 3$ down & 702.50 & 8.43 & 3.372 \\
& $2 / 3$ down & 977.50 & 11.73 & 4.692 \\
& end & 482.50 & 5.79 & 2.316 \\
& beginning & 795.00 & 9.54 & 3.816 \\
& $1 / 3$ down & $1,004.00$ & 12.05 & 4.820 \\
& $2 / 3$ down & 648.00 & 7.78 & 3.112 \\
& end & 851.00 & 10.21 & 4.084 \\
& beginning & 847.00 & 10.16 & 4.064 \\
& $1 / 3$ down & 861.00 & 10.33 & 5.132 \\
& $2 / 3$ down & $1,187.00$ & 14.24 & 2.840 \\
\hline
\end{tabular}

The volume applied per day to each plant was defined for irrigation time of 0.4 hour, considering that the crop needed $8 \mathrm{~L} /$ day of water and that the emitter operated at an average pressure of 42.6 $\mathrm{kPa}$. The system's performance parameters were determined from the data presented in Table 1. EU and $S U$ values were 74.51 and $77.69 \%$, respectively. These values classified the subunit's uniformity between bad and average to between average and good, respectively (ASAE EP458, 1996; Bralts et al., 1987). $C G V$ value $22.31 \%$ was considered acceptable according to Pizzaro (1996). $A e$ and $S e$ values were 100 and $47.83 \%$, respectively, while $D p$ and DD were 0 and $52.17 \%$, respectively, with $0 \%$ adequacy degree. Although the uniformity parameters showed that the system's performance was average, the efficiency parameters indicated that the system left much to be desired. It was decided to change this situation by increasing the irrigation times, and by calculating the efficiency parameters for each time again. Results are shown in Table 2.

The definition of the irrigation time is basically an economical decision. The watering time should progress as long as the increase in benefits exceed the additions in costs. In this analysis, benefits were considered to be the crop productivity as a function of greater availability of water in the soil, which would reduce areas showing hydraulic deficit and increase the storage efficiency. The costs would be mainly related to water losses due to a longer watering period. Regarding the difficulties in using an economical criterion, Frizzone (1997) suggested that the watering time increases should continue up to the point where the rate of decrease in $A e$ was equal to the rate of increase in Se. From the data in Table 2, a graphic was plotted (Figure 1) relating $A e, S e, D p$ and $D D$ 
for the time interval set for the analysis. From this graphic, the irrigation time in which the rate of decrease in $\mathrm{Ae}$ equals the rate of increase in $\mathrm{Se}$ was established, corresponding to $0.85 \mathrm{~h}$. Considering this new irrigation time, a new average watering program $(8.131 \mathrm{~L} /$ plant.day $)$ was defined, from which the new efficiency parameters were determined: $A e=90.20 \%, S e=91.68, D p=$ $9.80 \%, D D=8.32 \%$ and $a=52.87 \%$. The results showed that the system could operate with application and storage efficiencies at levels close to the minimum levels recommended in the literature, which range between 90 and $95 \%$ (Anyoji and $\mathrm{Wu}, 1994$ ).

Table 2 - System's efficiency parameters for different average water inputs at different irrigation times.

\begin{tabular}{ccccccc}
\hline $\begin{array}{c}\text { Irrigation } \\
\text { time } \\
\text { (hour) }\end{array}$ & $\begin{array}{c}\boldsymbol{V}_{\boldsymbol{o}} \\
\text { (L/plant.day) }\end{array}$ & $\boldsymbol{a}(\mathbf{\%})$ & $\boldsymbol{A e}(\mathbf{\%})$ & $\boldsymbol{S e} \mathbf{\%})$ & $\boldsymbol{D p}(\mathbf{\%})$ & $\boldsymbol{D D}(\mathbf{\%})$ \\
\hline 0.40 & 3.83 & 0 & 100 & 47.83 & 0 & 52.17 \\
0.50 & 4.78 & 0.14 & 100 & 59.79 & 0 & 40.21 \\
0.60 & 5.74 & 3.92 & 99.41 & 71.32 & 0.59 & 28.68 \\
0.70 & 6.69 & 19.21 & 97.56 & 81.66 & 2.44 & 18.34 \\
0.80 & 7.65 & 42.07 & 93.36 & 89.31 & 6.64 & 10.69 \\
0.90 & 8.61 & 62.55 & 87.13 & 93.77 & 12.87 & 6.23 \\
1.00 & 9.57 & 76.73 & 81.30 & 97.22 & 18.70 & 2.78 \\
1.10 & 10.52 & 85.77 & 74.94 & 98.58 & 25.65 & 1.42 \\
1.20 & 11.48 & 91.31 & 69.12 & 99.18 & 30.88 & 0.82 \\
1.30 & 12.44 & 94.52 & 64.09 & 99.63 & 35.91 & 0.37 \\
1.40 & 13.39 & 96.41 & 59.73 & 100 & 40.27 & 0 \\
\hline
\end{tabular}

\section{CONCLUSIONS}

It could be concluded from the results that the uniformity parameters showed that the subunit irrigated by means of the xique-xique system operated under regular conditions, according to the classifications used in this work. The present uniformity performance can be explained by the high coefficient of manufacturing variation of the orifices (emitters), as the manual process cannot be strictly controlled. As to the efficiency parameters, it was observed that changes in the subunit's management conditions and increases in the irrigation time enabled a maximization in application and storage efficiencies, noticeably improved the properly irrigated portion of the subunit and decreased the deficit degree with minor losses by deep percolation. Results showed importance of evaluating operating irrigation systems as a tool for characterizing their performance and suggesting changes when necessary.

\section{RESUMO}

Este trabalho apresenta a avaliação da irrigação quanto a uniformidade e eficiência de uma parcela de irrigação localizada pelo sistema xique-xique.

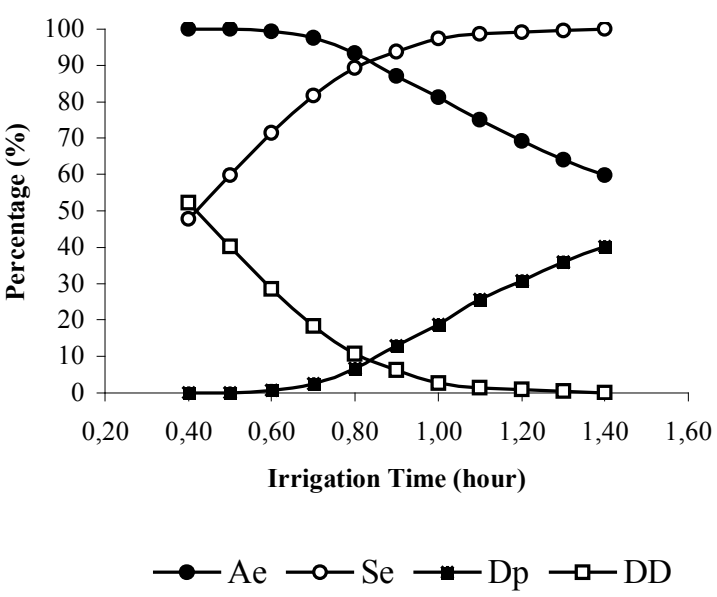

Figure 1 - $A e, S e, D p$ and $D D$ vs irrigation times.

Os resultados iniciais mostraram um desempenho regular do sistema no que diz respeito aos parâmetros de uniformidade, cujos valores de Uniformidade de Emissão, Uniformidade Estatística e Coeficiente de Variação Global foram de $74,51 \%, 77,69 \%$ e $22,31 \%$, respectivamente. Os parâmetros de eficiência ficaram abaixo da expectativa, sendo que os valores de Eficiência de Aplicação $(A e)$, Eficiência de Armazenamento $(S e)$, Perdas por Percolação $(D p)$, Grau de Déficit 
$(D D)$ e Grau de Adequação $(a)$ foram de $100 \%$, $47,83 \%, 0 \%, 52,17 \%$ e $0 \%$, respectivamente. Através da adoção de novas medidas de manejo foi possível melhorar a eficiência do sistema, alcançando-se valores de 90,20\%, 91,68\%, 9,80\%, $8,32 \%$ e $52,87 \%$ para a $E a, E s, P p, G D$ e $a$, respectivamente.

\section{REFERENCES}

Anyoji, H. and Wu, I. P. (1994), Normal distribution water application for drip irrigation schedules. Transaction of the ASAE, 37159-164.

ASAE - American Society of Agricultural Engineers. EP458 (1996), Field Evaluation of Microirrigation Systems, 792-797.

Bralts, V. F. and Edwards, D. M. (1986), Field evaluation of drip irrigation submain units. Transaction of the ASAE, 291659-1664.

Bralts, V. F. and Kesner, C. (1982), Drip irrigation field uniformity estimation. Transactions of the ASAE, 24, 1369-1374.

Bralts, V. F.; Wu, I. P. and Gitlin, H. M. (1981), Manufacturing variation and drip irrigation uniformity. Transaction of the ASAE, 24, 113-119.

Bralts, V. F.; Edwards, D. M. and Wu, I. P. (1987), Drip irrigation design and evaluation based on the statistical uniformity concept. In: Hillel, D. (ed.). Advances in Irrigation. Massachusetts : Academic Press, Inc., Amherst. pp. 67-117.

Frizzone, J. A. (1997), Uniformidade e eficiência da irrigação. Departamento de Engenharia Rural, ESALQ, Série didática, Piracicaba. pp. 2-18.

Keller, J. and Bliesner, R. D. (1990), Sprinkle and trickle irrigation. van Nostrand Reinhold, New York. pp. 427-602.
Keller, J. and Karmeli, D. (1974), Trickle irrigation design parameters. Transaction of the ASAE, 7, 678-684.

Martin-Benito, J. M. T. (1993), La aplicacion del agua el riego y su evaluacion. In: Olalla Mañas, F. M. S. (ed.).Agronomia del riego. Ediciones Mundi-Prensa, Madri. pp.615-694.

Merrian, J. L. and Keller, J. (1978), Farm irrigation system evaluation: A guide for management. Logan: Agricultural and Irrigation Engineering Department, Utah State University. pp.120-230.

Pizzaro, F. (1996), Riego localizados de alta frequencia. 2.ed. Madrid : Ediciones Mundi Prensa. pp.397-409.

Solomon, K. (1979), Variability sprinkler coefficient of uniformity test results. Transaction of the ASAE, 22, 1078-1080.

Wilcox, J. C. and Swailes, G. E. (1947), Uniformity of water distribution by some undertree orchard sprinklers. Scientific Agriculture, 27, 565-583.

Zelen, M. and Severo, N. C. (1972), Probability functions. In: Abramowitz, M. and Stegun, I.A. (eds.). Handbook of mathematical functions with formulas, graphs, and mathematical tables. United States Department of Commerce, National Bureau of Standards, Washington. pp. 925-995.

Received: May 18, 2001; Revised: September 04, 2001; Accepted: December 17, 2001. 